be very much the same as those in the earlier period. The school science masters claim that they have adopted new methods of teaching. Secondly, as to the supply of candidates, I feel sure if consideration is taken of all classes of schools in the country it will be found that there is a very large number of boys keenly interested in science.

I will submit two suggestions. First, that closer touch with the Jocal education authorities is necessary. Each local authority has a director or secretary who looks after the progress of the boys in his district. The directors are acquainted with the best boys through their local scholarship schemes, and should be able to point out at once the boys likely to make progress. Selection might in certain cases be made on their recommendation only. I will not go further into this means of connecting the universities and the schools, beyond saying that something of the kind exists in certain districts.

I believe that the present form of scholarship does not recommend itself to the less wealthy, and my second suggestion is that some scholarships might take the form of free places, to include education, board and lodging, and a small money grant. I find that the fear of unforeseen incidentals deters many from the thought of a career at Cambridge. The free place should remove this fear.

My experience leads me to think that a Cambridge career under such conditions would appeal to a very much wider field than at present.

\section{Sidney Skinner.}

\section{Science in the Civil Service.}

I HAVE read with sustained interest your leading article on science in the public schools and the Civil Service. The preference given to classical subjects in the competitive examinations for higher appointments in the Civil Service is patent. This might be remedied, as you appear to suggest, by a different allocation of marks to the various subjects of the examination. But are there not serious objections to the whole system of competitive examinations as applied to these appointments? I venture to suggest that the system should be ended rather than mended-" off with his head," as the Red Queen would say, with admirable directness.

With your permission, I will briefly recapitulate the arguments for such drastic treatment, which I discussed in detail in a paper read at the Teachers' Guild annual conference in January, x913. The system tends to impose upon universities and colleges an official or bureaucratic curriculum. In so far as it fails to do this, it divides the attention of the student between his university and an external authority. The result may be illustrated from the subjects selected at the competitive examination by the first successful candidate in I9II, representing a course of study which no university in the world would willingly impose upon its students :-English composition, French, mathematics, physics, logic and psychology, moral and metaphysical philosophy, political economy and economic history, and political science. The allocation of marks to various subjects and the arrangement of candidates in an order of merit on an aggregate of marks in a wide variety of subjects must be arbitrary and unscientific. No credit can be given for original literary or scientific work, and no provision is made for the specialisation of study which, within limits, may be desirable for the future work of the successful candidates. There can be no guarantee that various types of training are fairly represented among the successful candidates. Aptitude for administrative work is in no way specifically tested. The top candidate who, from the point of view of scholarship, may be too good, and the last successful candidate, who may not be good enough, are equally accepted. Restricted age limits are a necessary condition of the system. It does not provide fairly for the promotion of men already in the Service. It is unsuitable for women, to whom the privilege of admission to higher appointments in the Civil Service will, without doubt, be more generally conceded in the near future. Indeed, the physical and mental strain which the system entails must be harmful to men in many cases. The need for expensive special preparation handicaps the poorer student. In practice, the system works unfairly as between the students of the old and the modern universities. This is notorious, but the figures for the five years 1906-10 may be quoted. Out of 473 successful candidates, 247 (more than half) came from Oxford, and 142 from Cambridge; only five came from London, two from Manchester, and one from Leeds.

A system of selection on record by a properly constituted board would meet all these criticisms, and might be applied also to the numerous professional appointments now made departmentally. Owing to the war, such a system is already in operation for a certain proportion of the appointments to the Indian Civil Service. I have not much doubt that if the public, as represented by the universities and the learned societies, were to ask for this reform it would be granted. There would not be much official opposition, for $\mathrm{Mr}$. Leathes, the First Civil Service Commissioner, when asked by the Royal Commission on the Civil Service if, supposing alr ideas of the misuse of patronage were excluded, the best way of appointment would not be by selection and nomination, answered in the affirmative, provided that you could trust your nominating authority to be not oniy absolutely honest, but also always industrious, and to have a highly developed judgment. He thougint that then, ideally, selection would undoubtedly be superior, but feared that both history and experience had proved that it was an impossible way. The war has intervened since the pronouncement, and we are now, I hope, more disposed to suppress fears and prejudices in face of facts and arguments.

T. Ll. Humberstone.

2 I Gower Street, W.C., February 20.

\section{The Place of Science in Education.}

SrR Edward SchäfER will doubtless carry many with him in advocating a revolution in our educational system in favour of making science the foundation of the education given in our secondary schools. But the difficult question remains as to how that can be done. In the memorandum he refers to, a definite step was proposed towards the desired end. Sir Edward Schäfer considers it a halting step, but he does not suggest any alternative course whereby the public can be led to demand that its educational house should be put in order. As one who had some small share in drawing up the memorandum, may I ask Sir Edward Schäfer what course he would like to see adopted in place of the one already indicated?

I I Airlie Gardens, Campden Hill, W.

\section{Latin as a Universal Language.}

I HAve read with interest the letter of Sir Lauder Brunton on Latin as a universal language. I sincerely hope the matter will not be allowed to drop. As a contribution, may I say that we have taught Latin here as a spoken language for fourteen years past, just as French and German are taught, and the 